Editorial

\title{
Covid-19 Pandemic: The Use of Protective Visor in the Dentistry Degree Course of Dental Prosthetics Technology of the University of Messina
}

\author{
Marco Cicciù * $(\mathbb{0}$, Gabriele Cervino $\unrhd$ and Sergio Baldari \\ Department of Biomedical and Dental Sciences and Morphological and Functional Imaging, Messina University, \\ 98100 Messina, Italy; gcervino@unime.it (G.C.); sbaldari@unime.it (S.B.) \\ * Correspondence: mcicciu@unime.it
}

Received: 9 October 2020; Accepted: 12 October 2020; Published: 14 October 2020

check for updates

The severe acute respiratory syndrome coronavirus 2 (SARS-CoV-2) is responsible for the coronavirus disease 2019 (COVID-19). The incubation period of this infectious disease varies from about 2 to 14 days (with some reported cases of 29 days), during which time the patient could be contagious [1,2]. COVID-19 is due to coronavirus SARS-CoV-2 infection. The new coronavirus was named coronavirus SARS-CoV-2 by the coronavirus study group of the International Committee on Taxonomy of Viruses (the commission responsible for classifying and naming viruses) because it was considered to be a "brother" of the virus responsible for SARS (SARS-CoV) [1-7].

COVID-19 is a respiratory virus that spreads mainly through contact with the respiratory droplets of infected people, direct mucous contact with saliva droplets or by mucous contact with those droplets on hands, on objects or on infected surfaces [8-10].

Although the transmission modalities of the virus are not fully understood yet, it has been confirmed that it is capable of passing from human to human. A public health official in Washington State in the United States noted that coronaviruses are mainly transmitted "through close contact with another individual, particularly by coughing and sneezing on someone else who is within a range of about $1-2 \mathrm{~m}$ from that person".

It is believed, in fact, that in most cases, the spread between people occurs through the respiratory droplets emitted by an infected individual when coughing or sneezing which, subsequently, are inhaled by a healthy person who is nearby.

It is possible to become infected even after touching surfaces or objects where the virus is present, then bringing the hands towards one's mouth or towards the nose or eyes. The virus, under ideal conditions, can in fact persist on different surfaces for hours or days [11-15].

Although respiratory viruses are usually transmissible when the infected person also has symptoms, it would appear that SARS-CoV-2 can spread even in close contact with asymptomatic patients.

In recent months, the life of each and every one of us has been turned upside down due to the COVID-19 epidemic, a moment that is complicating the work of all universities in terms of face-to-face lessons. People all over the world are trying to minimize infections through social distancing.

The most effective measure in the fight against the spread of COVID-19 has a name: social distancing. This involves maintaining physical distance and using masks as well as frequent hand washing.

The recommendations issued by various national and international institutional authorities are variable: the Ministry of Health prescribes that "in the presence of other people, a distance of at least one meter must be kept and any direct contact (including handshakes, kisses and hugs) must be absolutely avoided."

Studies show a strong correlation between proximity to exposure and the risk of infection. Although some studies were performed in COVID-19 outbreaks, the relationship is independent of 
the viral species (it depends on the mode of transmission, not on the infectious agent). A reduction in the risk of infection of $82 \%$ was found one meter away, both in the healthcare setting and in the community (adjusted odds ratio 0.18 ; $95 \%$ CI $0.09-0.38$ ). Each additional meter of separation increases the protective effect more than twice (relative risk variation-RR 2.02 per meter; $p=0.041$ ).

(Physical distancing, face masks and eye protection to prevent person-to-person transmission of SARS-CoV-2 and COVID-19: a systematic review and meta-analysis Lancet 2020; 395: 1973-87).

Studies published so far confirm that the use of face masks is protective for both healthcare personnel and the general population, and that the use of eye protection confers additional benefits.

For all these reasons, the Degree Course in Dentistry and Dental Prosthetics at the University of Messina has recently introduced a project called \#unimesicura which was developed after the latest provisions of the Academic Senate, which unanimously approved the return of students to classrooms on October 5th. The new measures provide lectures in which all students are equipped with protective face shields that, along with the use of masks, help to further protect against aerosol production inside the classrooms.

Social distancing beyond one meter will be guaranteed in each classroom and the students will wear visors as additional protection (Figure 1).

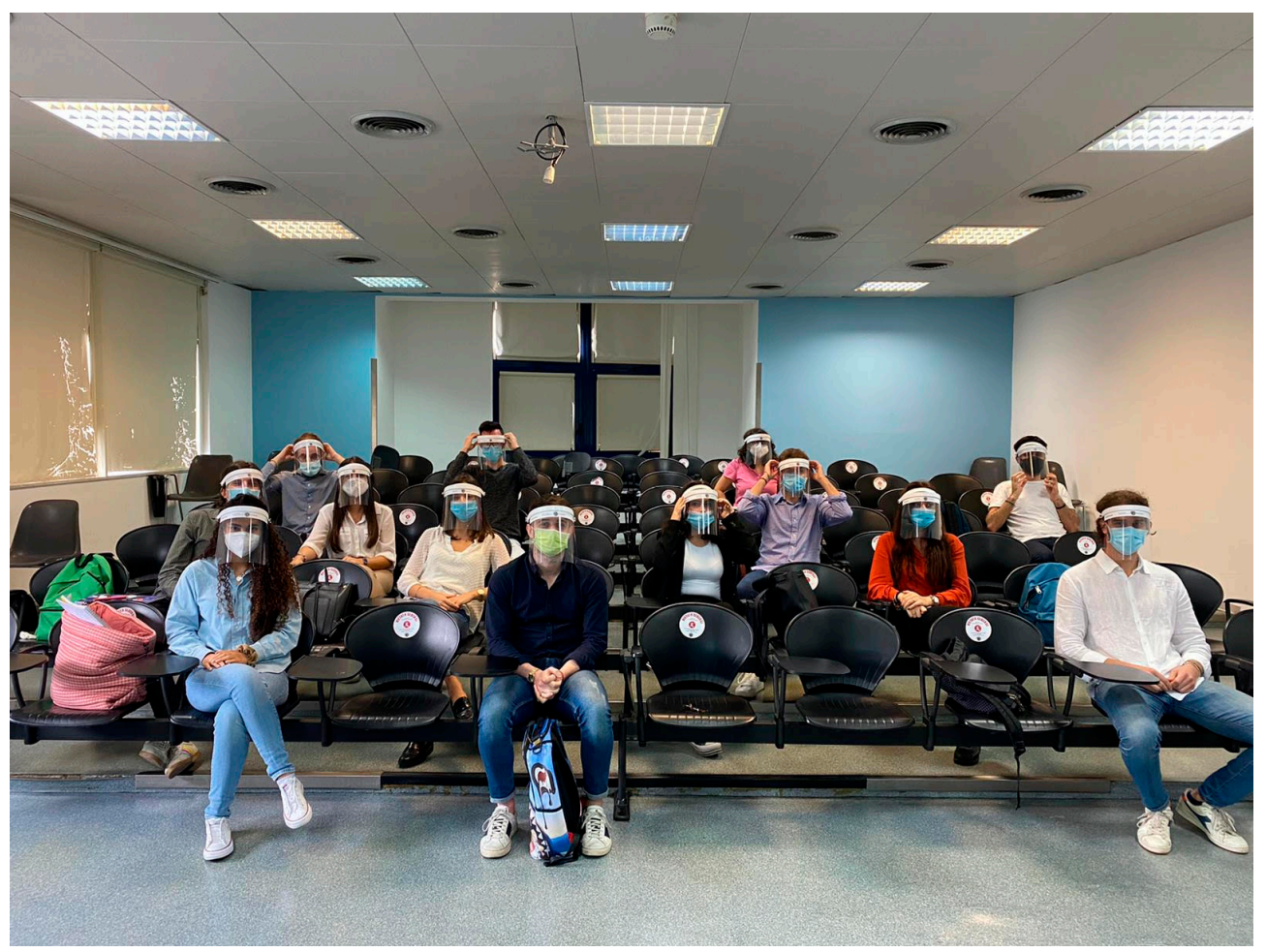

Figure 1. Classroom with protective visors.

This, along with the aforementioned measures, could allow for containing the spread of the virus in common spaces.

The visors supplied to students have been personalized with their own name to avoid being exchanged between students and to give a unanimous and institutional aspect to the University of Messina, which, at the moment, seems to be the first in Italy to have adopted this system. 
The visors are made of an ultra-light material to allow students to wear them for many hours, a foam rubber band has been inserted at the forehead to make it more comfortable and the fixing screws of the mask allow to fasten the protective mask in order to avoid the discomfort of the traction that occurs on the helix of the ear.

This model could enhance the effectiveness of social distancing in closed environments, increased by the further use of face protection.

As a matter of fact, many authors have argued that the use of face masks for asymptomatic individuals as a public health intervention could interrupt the chain of transmission by blocking apparently healthy sources of infection. Regardless of whether the person using a face mask is protected or not, its use could block the transmission by limiting the spread of infectious particles. Community transmission could be reduced if everyone, including asymptomatic and symptomatic people, wore face masks.

Author Contributions: Writing-review and editing, G.C.; writing-review and editing; M.C.; supervision, S.B. All authors have read and agreed to the published version of the manuscript.

Funding: This research received no external funding.

Conflicts of Interest: The authors declare no conflict of interest.

\section{References}

1. Zhang, W.; Wang, Y.; Yang, L.; Wang, C. Suspending Classes Without Stopping Learning: China's Education Emergency Management Policy in the COVID-19 Outbreak. J. Risk Financ. Manag. 2020, 13, 55. [CrossRef]

2. Yu, H.; Sun, X.; Solvang, W.D.; Zhao, X. Reverse Logistics Network Design for Effective Management of Medical Waste in Epidemic Outbreaks: Insights from the Coronavirus Disease 2019 (COVID-19) Outbreak in Wuhan (China). Int. J. Environ. Res. Public Health 2020, 17, 1770. [CrossRef] [PubMed]

3. Yang, Y.; Shang, W.; Rao, X. Facing the COVID-19 outbreak: What should we know and what could we do? J. Med. Virol. 2020, 92, 536-537. [CrossRef] [PubMed]

4. Fiorillo, L.; Cervino, G.; Matarese, M.; D’Amico, C.; Surace, G.; Paduano, V.; Fiorillo, M.T.; Moschella, A.; La Bruna, A.; Romano, G.L.; et al. COVID-19 Surface Persistence: A Recent Data Summary and Its Importance for Medical and Dental Settings. Int. J. Environ. Res. Public Health 2020, 17, 3132. [CrossRef] [PubMed]

5. Xu, B.; Kraemer, M.U.G. Open access epidemiological data from the COVID-19 outbreak. Lancet Infect. Dis. 2020, 20, 534. [CrossRef]

6. Wu, Z.; McGoogan, J.M. Characteristics of and Important Lessons from the Coronavirus Disease 2019 (COVID-19) Outbreak in China: Summary of a Report of 72314 Cases from the Chinese Center for Disease Control and Prevention. JAMA 2020, 323, 1239-1242. [CrossRef] [PubMed]

7. Wang, C.; Pan, R.; Wan, X.; Tan, Y.; Xu, L.; Ho, C.S.; Ho, R.C. Immediate Psychological Responses and Associated Factors during the Initial Stage of the 2019 Coronavirus Disease (COVID-19) Epidemic among the General Population in China. Int. J. Environ. Res. Public Health 2020, 17, 1729. [CrossRef] [PubMed]

8. Wang, C.; Cheng, Z.; Yue, X.-G.; McAleer, M. Risk Management of COVID-19 by Universities in China. J. Risk Financ. Manag. 2020, 13, 36. [CrossRef]

9. Cervino, G.; Fiorillo, L.; Surace, G.; Paduano, V.; Fiorillo, M.T.; De Stefano, R.; Laudicella, R.; Baldari, S.; Gaeta, M.; Cicciù, M. SARS-CoV-2 Persistence: Data Summary up to Q2 2020. Data 2020, 5, 81. [CrossRef]

10. Fiorillo, L. Oral Health: The First Step to Well-Being. Medicina 2019, 55, 676. [CrossRef] [PubMed]

11. The Lancet. COVID-19: Fighting panic with information. Lancet 2020, 395, 537. [CrossRef]

12. Cavallo, L.; Marcianò, A.; Cicciù, M.; Oteri, G. 3D Printing beyond Dentistry during COVID 19 Epidemic: A Technical Note for Producing Connectors to Breathing Devices. Prosthesis 2020, 2, 5. [CrossRef]

13. Cervino, G.; Oteri, G. COVID-19 Pandemic and Telephone Triage before Attending Medical Office: Problem or Opportunity? Medicina 2020, 56, 250. [CrossRef] [PubMed] 
14. Liu, Z.; Magal, P.; Seydi, O.; Webb, G. Understanding Unreported Cases in the COVID-19 Epidemic Outbreak in Wuhan, China, and the Importance of Major Public Health Interventions. Biology 2020, 9, 50. [CrossRef] [PubMed]

15. Roosa, K.; Lee, Y.; Luo, R.; Kirpich, A.; Rothenberg, R.; Hyman, J.M.; Yan, P.; Chowell, G. Short-term Forecasts of the COVID-19 Epidemic in Guangdong and Zhejiang, China: February 13-23, 2020. J. Clin. Med. 2020, 9, 596. [CrossRef] [PubMed]

Publisher's Note: MDPI stays neutral with regard to jurisdictional claims in published maps and institutional affiliations.

(C) 2020 by the authors. Licensee MDPI, Basel, Switzerland. This article is an open access article distributed under the terms and conditions of the Creative Commons Attribution (CC BY) license (http://creativecommons.org/licenses/by/4.0/). 